\title{
Læknirinn sem vísindamaður - rannsóknarpjálfun læknanema og lækna
}

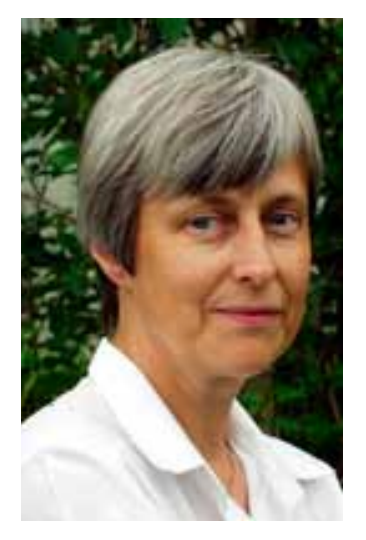

Helga M. Ögmundsdóttir

helgaogm@hi.is

Höfundur er sérfræðingur í ónæmisfræði og prófessor í frumulíffræði við Háskóla Íslands, formaður rannsóknarnámsnefndar læknadeildar og í forsvari fyrir rannsóknastofu deildarinnar krabbameinsfræðum.

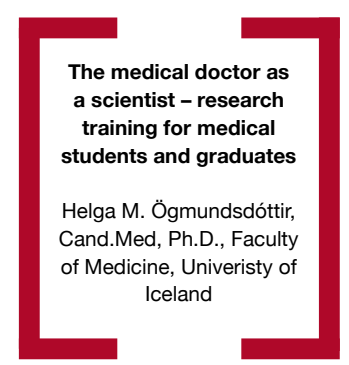

Fyrsta doktorsgráðan frá læknadeild Háskóla Íslands var veitt 1933 en formlegt doktorsnám hófst við deildina árið 1995. Doktorsvarnir hafa verið fimm til sjö talsins á ári síðastliðin fimm ár. Hafa ber í huga að læknar eru aðeins fimmtungur af um pað bil 60 doktorsnemum við læknadeild. Fyrir fáeinum árum tóku unglæknar að innritast í meistaranám við læknadeild. Petta virðist hafa verið bylgja sem reis og féll svo aftur, pví að enginn unglæknir innritaðist síðastliðið ár. Vert væri að leita skýringa á pessu áhugaleysi nú.

En hvað hvetur unga lækna til vísindastarfa og pá sérstaklega til meistara- eða doktorsnáms? Ein ástæðan er metnaður í námi og starfi, rannsóknargráđa greiðir götuna til sérnáms á bestu stöðum. En pað er annað og meira, og fáir munu endast í rannsóknum ef innri hvatann vantar. Vísindaleg pjálfun er verðmætt veganesti fyrir ævistarfið, jafnvel pótt rannsóknir skipi par ekki háan sess. Рað mikilvægasta við doktorsnámið er ekki viðfangsefnið og ritgerðin heldur pað að hafa farið pessa leið og tekið út pann proska sem hún felur í sér og geta staðið sjálfstætt sem vísindamaður. Doktorsgráðan opnar vissulega möguleikann á akademískum starfsferli en nýtist á margan annan hátt.

Íslenskir læknar sækja sérmenntun til margra landa og algengt er að menn hafi fengið tækifæri til vísindastarfa. Í Svípjóð fer pað oft fram innan ramma doktorsnáms en í Bandaríkjunum er slíkt nám gjarnan skipulagt jafnhliða grunnnámi í læknisfræði (sem par er á 2. stigi háskólanáms), sem MD-PhD og hentar pað skipulag ekki vel fyrir erlenda lækna í sérnámi. Allnokkrir íslenskir læknar hafa notfært sér pann möguleika í reglum læknadeildar HÍ um doktorsnám að geta innritast á miðri leið. Pá er metin vísindavinnan sem pegar hefur verið unnin og menn fá formlega handleiðslu við lokahnykkinn, pað er að setja verkið saman í heildstæða doktorsritgerð.

Fjármögnun rannsókna er ekki auðveld, eins og talsvert hefur verið rætt að undanförnu. Háskólinn og RANNís hafa í nokkur ár veitt doktorsstyrki. Með ört vaxandi framboði á doktorsnámi við HÍ er ásóknin mikil og árangurshlutfall um priðjungur. Hér á landi vantar alveg fjármögnun til rannsókna úr hinum svokallaða priðja geira, sem er mjög mikilvægur víða erlendis. Par koma að fyrirtæki, hollvinasamtök, stuðningssamtök og stórefnamenn. Til eru dæmi um að sérgreinafélög íslenskra lækna reki litla vísindasjóði sem ungir vísindamenn í viðkomandi sérgrein hafa notið góðs af. Petta pyrfti að efla til muna. Раð mætti hugsa sér að stofnaðir yrðu sjóðir sem læknar gætu lagt í til pess að styrkja efnilega læknanema og unglækna til doktorsnáms, til dæmis á tilteknum sérsviðum.

Læknar hafa nokkra sérstöðu í náms- og starfsferli að pví leyti að á sama tíma og annað háskólafólk einbeitir sér að akademísku doktorsnámi eru peir í krefjandi klínísku sérnámi. Petta tvennt er ekki auðvelt að sameina. •að gildir um pjálfun í rannsóknum og vísindum, rétt eins og um annað nám, að best er að byrja snemma. Petta er hugsunin á bak við bandaríska MD-PhD námið og ýmis dæmi eru um doktorsnám samhliða grunnnámi í læknisfræði á Norðurlöndum. Reglur um doktorsnám við Háskóla Íslands hafa leyft pennan möguleika frá upphafi. Einn nemandi hefur fram að pessu notfært sér hann og er viðtal við hann í pessu tölublaði Læknablaðsins. Er athyglisvert að grípa aðeins niður í pað sem pessi efnilegi ungi vísindamaður segir. Hann talar um pann vanda að hafa áhuga á flestu sem hann hefur kynnst í læknanáminu, drauminn um að geta sameinað rannsóknir og klíníska læknisfræði og að hann sjái fyrirmyndir í mörgum sérfræðingum Landspítala sem hefur tekist að sameina farsælan feril í vísindarannsóknum og klíníska læknisfræði. Parna er með öðrum orðum innri hvatinn og vandinn við að sameina vísindi og klínískt starf sem áður var nefnt, og við bætist gildi góðra fyrirmynda, sem eru mjög mikils virði. Innan læknadeildar HÍ verða á næstunni stigin fyrstu skrefin við að formfesta skipulag doktorsnáms samhliða grunnnámi í læknisfræði.

Pað er ekki kappsmál í sjálfu sér að mikill fjöldi lækna ljúki doktorsnámi. Gæðin skipta mestu máli. Reyndir erlendir andmælendur við doktorsvarnir við læknadeild HÍ hafa látið pau orð falla að petta sé besta ritgerð sem peir hafi dæmt. Рað verða aldrei margir í hverjum árgangi sem kjósa að fara pessa leið og peir purfa að leggja hart að sér. Pess vegna parf hvatinn að vera sterkur og mikilvægt að áhuginn sé einlægur. Spítalinn og háskólinn purfa að vinna saman að pví að búa pessu fólki pau skilyrði að pað fái að njóta sín og geti sinnt bæði klíníkinni og akademíunni með sóma. 